\title{
Effects of glucose and insulin on glucokinase activity in rat hypothalamus
}

\author{
Carmen Sanz, Isabel Roncero, Patricia Vázquez, M Angeles Navas and Enrique Blázquez
}

Department of Biochemistry and Molecular Biology, Faculty of Medicine, Complutense University, 28040 Madrid, Spain

(Requests for offprints should be addressed to C Sanz; Email: mcsanz@med.ucm.es)

\begin{abstract}
In an attempt to study the role of glucokinase (GK) and the effects of glucose and peptides on $G K$ gene expression and on the activity of this enzyme in the hypothalamus, we used two kinds of biological models: hypothalamic GT1-7 cells and rat hypothalamic slices. The expression of the GK gene in GT1-7 cells was reduced by insulin (INS) and was not modified by different glucose concentrations, while GK enzyme activities were significantly reduced by the different peptides. Interestingly, a distinctive pattern of GK activities between the ventromedial hypothalamus (VMH) and lateral hypothalamus (LH) were found, with higher enzyme activities in the VMH as the glucose concentrations rose, while LH enzyme activities decreased at 2.8 and $20 \mathrm{mM}$ glucose, the latter effect being prevented by incubation with INS. These effects were
\end{abstract}

produced only by D-glucose and the modifications found were due to GK, but not to other hexokinases. In addition, GK activities in the $\mathrm{VMH}$ and the $\mathrm{LH}$ were reduced by glucagonlike peptide 1, leptin, orexin B, INS, and neuropeptide Y (NPY), but this effect was only statistically significant for NPY in LH. Our results indicate that the effects of both glucose and peptides occur on GK enzyme activities rather than on GK gene transcription. Moreover, the effects of glucose and INS on GK activity suggest that in the brain GK behaves in a manner opposite to that in the liver, which might facilitate its role in glucose sensing. Finally, hypothalamic slices seem to offer a good physiological model to discriminate the effects between different areas.

Journal of Endocrinology (2007) 193, 259-267

\section{Introduction}

Glucokinase (GK) is a type IV isoenzyme that belongs to the family of hexokinases (ATP: D-hexose 6-phosphotransferase; EC 2.7.1.1) and catalyzes the formation of glucose 6 phosphate in eukaryotic cells. This isoenzyme (Dipietro et al. 1962, Viñuela et al. 1963) has a molecular mass of $52 \mathrm{kDa}$ and a low affinity for glucose and is not subject to feedback inhibition by glucose 6-phosphate.

GK activity is expressed in liver (Printz et al. 1993), the pancreatic islets of Langerhans (Matschinsky \& Ellerman 1968), jejunal enterocytes, neuroendocrine cells, and brain (Jetton et al. 1994, Navarro et al. 1996, Roncero et al. 2000). GK is encoded by a single gene, but the presence of alternative promoters (Magnuson \& Shelton 1989) allows the cell-specific expression of this protein with differential regulation. Thus, liver GK is regulated by insulin (INS) (Printz et al. 1993), whereas the pancreatic enzyme seems to be controlled posttranslationally by glucose levels (Matschinsky \& Ellerman 1968). Along the same lines, brain GK should be controlled by glucose levels and this is one of the issues studied here.

GK plays a key role in the glucose metabolism of the liver and it is considered to be a glucose sensor in pancreatic $\beta$-cells involved in glucose-dependent INS release (Matschinsky 1990), as well as in hepatocytes and hypothalamic neurons (Alvarez et al. 1996, Navarro et al. 1996, Kang et al. 2006). At least two kinds of glucose sensor neurons have been identified in brain. Glucose-excited (GE) neurons are present mainly in the ventromedial hypothalamus (VMH) neurons of the hypothalamus and they are excited by increased glucose levels in the extracellular space, with alterations in their firing rates (Oomura et al. 1969). By contrast, the glucose-inhibited (GI) neurons, mainly present in the lateral hypothalamus (LH) area, are excited by the decrease in glucose in the extracellular space. GK seems to be the mediator of glucose sensing in both GE and GI neurons (Dunn-Meynell et al. 2002). When GE neurons are exposed to high-glucose levels, GK activation produces an increase in the ATP/ADP ratio, after which the $\mathrm{K}_{\mathrm{ATP}}^{+}$ channel (Dunn-Meynell et al. 1998) is inactivated, producing membrane depolarization. As a consequence, a $\mathrm{Ca}^{2+}$ influx through a voltage-activated $\mathrm{Ca}^{2+}$ channel occurs. Although $\mathrm{K}_{\text {ATP }}^{+}$channel distribution is ubiquitous in brain, only selective areas of this organ show glucose-sensing properties, which seems to be governed by the activity of GK. Contrariwise, when glucose levels decrease, $\mathrm{Ca}^{2+}$ oscillations increase in GI cells but are reduced in GE neurons (Niimi et al. 1995).

It has been suggested that GK may recognize elevations in plasma glucose levels after food ingestion and its interactions 
with the glucokinase regulatory protein (GKRP) may facilitate the functioning of glucose-sensing sites located in selective neurons of the hypothalamus and hindbrain (Alvarez et al. 1996, 2002). In keeping with this proposal, groups of these cells containing orexigenic and anorexigenic peptides and their receptors may produce integrated responses to modifications in metabolites, enabling them to act as sensors of glucose circulating levels. To test this working hypothesis, we determined the effects of different glucose concentrations and orexigenic and anorexigenic peptides on GK gene expression and GK activity in GT1-7 and rat hypothalamic slices.

\section{Materials and Methods}

\section{Experimental animals}

All procedures involving animals were approved by the appropriate institutional review committee and met the guidelines for the care of animals specified by the European Community. Male Wistar rats weighing 150-175 g were fed ad libitum with a standard pellet diet and housed at a constant temperature $\left(21^{\circ} \mathrm{C}\right)$ on a $12 \mathrm{~h}$ light: $12 \mathrm{~h}$ darkness cycle with lights on at $0800 \mathrm{~h}$. Rats were killed by decapitation under non-fasting state, and the whole brain was rapidly removed and placed in ice-cold medium. All procedures were carried out according to the European Union ethical regulations for animal research.

\section{Cell cultures and GK promoter activity assays}

The GT1-7 cell line (generously provided by Prof. P Mellon, Department of Reproductive Medicine, School of Medicine, University of California, San Diego, CA, USA), transformed from mouse hypothalamic neurosecretory cells (Mellon et al. 1990), is an excellent tool for neuronal studies (Wetsel 1995). GT1-7 cells were maintained in Dulbecco's modified Eagle's medium (DMEM, Life Technologies) containing $4.5 \mathrm{~g} / 1$ glucose, $10 \%$ fetal bovine serum (Biomedia, Boussens, France), $100 \mathrm{U} / \mathrm{ml}$ penicillin, $100 \mu \mathrm{g} / \mathrm{ml}$ streptomycin, and $2 \mathrm{mM}$ glutamine (Biomedia). The wild-type reporter gene construct (generously provided by Dr Magnuson, Department of Molecular Physiology and Biophysics, Vanderbilt University Medical Center, Nashville, TN, USA) was created by cloning $1014 \mathrm{bp}$ pancreatic rat GK promoter $(-1000$ to +14 ) into the promoterless luciferase vector pSVOAPL2L (Shelton et al. 1992). Transfection was performed using calcium phosphate precipitates containing $3 \mu \mathrm{g}$ luciferase expression vector with the $G c K$ promoter, and $1 \mu \mathrm{g}$ internal control plasmid pCMV-Bgalactosidase for each well of a 12 multiwell plate. GT1-7 cells were incubated with calcium phosphate precipitates for 14-16 $\mathrm{h}$ and then rinsed and kept in fresh medium for $24 \mathrm{~h}$. Following this, the cells were incubated overnight in the presence of medium containing $2 \%$ fetal bovine serum (FBS) and $5.5 \mathrm{mM}$ glucose. The medium was then removed and replaced by DMEM containing $2 \%$ Fetal bovine serum (FBS) and different glucose and/or peptide concentrations. After $5 \mathrm{~h}$ of treatment, the cells were lysed, and luciferase activity was determined with a luminometer (BG-P luminometer, GEM Biomedical, Hamdem, CT, USA). Luciferase activity levels, normalized with $\beta$-galactosidase activities are expressed as fold stimulation of control $(5.5 \mathrm{mM}$ glucose) values.

\section{$R N A$ isolation and semiquantitative RT-PCR analysis of GK $m R N A$}

Total RNA from culture were extracted with TRIZOL (Life Technologies). The purity of the RNA was assayed by electrophoresis in agarose gel. One microgram total RNA was transcripted to obtain $20 \mu \mathrm{l}$ cDNA (RETROscript Ambion, Austin, TX, USA). Five microlitres cDNA were used as template for the PCR, following the manufacturer's instructions (Biotools B\&M Labs SA, Madrid, Spain). The pancreatic-specific primers for the GK amplification were 5'AATCTTGCGGAACACTGAG3' and $5^{\prime}$ CACGTAGGTGGTAACATCTTTACAC $3^{\prime}$. To control the differences in initial RNA levels and tube-to-tube variations in PCR, a primer pair for $18 \mathrm{~S}$ was included in each PCR amplification. The control 18S amplification primers were $5^{\prime}$ TCAAGAACGAAAGTCGGAGG $3^{\prime}$ and $5^{\prime}$ GGACATCTAAGGGCATCACA $3^{\prime}$. The conditions used were as follows: $94^{\circ} \mathrm{C}$ for $2 \mathrm{~min}$, followed by 35 cycles at $94{ }^{\circ} \mathrm{C}$ for $30 \mathrm{~s}, 58^{\circ} \mathrm{C}$ for $30 \mathrm{~s}, 72^{\circ} \mathrm{C}$ for $1 \mathrm{~min}$, and a final extension cycle at $72{ }^{\circ} \mathrm{C}$ for $10 \mathrm{~min}$.

\section{Procedure for hypothalamic-slice explants culture}

Hypothalamic-slice explants cultures were performed as described previously (House et al. 1998, Arima et al. 2001). Male Wistar rats were killed by decapitation and the brains were quickly removed and immersed in cold $\left(4^{\circ} \mathrm{C}\right)$ MEM medium containing $25 \mathrm{mM}$ HEPES, $20 \%$ heat-inactivated horse serum, $4 \mathrm{mM}$ glutamine, $6.5 \mathrm{mg} / \mathrm{ml}$ glucose, and $100 \mathrm{U} / \mathrm{ml}$ penicillin-streptomycin. Following this, the hypothalamus was removed from the brain and sectioned at $300 \mu \mathrm{m}$ thickness on a Mcllwain tissue chopper (Mickle Laboratory Engineering Co., Surrey, UK). Coronal slices were separated and placed in MEM supplemented with 25 mM HEPES and Hank's salt (Life Technologies) enriched with the above components. In an attempt to stabilize the cultures, hypothalamic slices were cultured at $37^{\circ} \mathrm{C}$ in an atmosphere of air and $\mathrm{CO}_{2}$ (95:5\% respectively) in the medium (MEM, 25 mM HEPES with Hank's salt, 20\% heatinactivated horse serum, $4 \mathrm{mM}$ glutamine, $6.5 \mathrm{mg} / \mathrm{ml}$ glucose, and $100 \mathrm{U} / \mathrm{ml}$ penicillin-streptomycin) for $5 \mathrm{~h}$. Then, the hypothalamic slices were transferred to a medium containing $2 \%$ FBS and $5.5 \mathrm{mM}$ glucose and incubated for $16 \mathrm{~h}$. The cell viability of the hypothalamic slices was determined by the addition of $0.5 \mu \mathrm{g} / \mathrm{ml}$ propidium iodide to the culture medium or by incubating the slices in a solution 
containing $1 \mathrm{ml}$ Trypan blue solution $(0.8 \mathrm{mM}$ in PBS) and $1 \mathrm{ml}$ culture medium. After at least $15 \mathrm{~min}$ of incubation, propidium staining was assessed with an inverted fluorescence microscope, using a standard rhodamine filter set. In the case of trypan blue, cell viability was determined under a light microscope 5 min after incubation with the stain.

To examine the effects of different glucose concentrations and/or peptides on GK enzyme activities in hypothalamic slices, these were incubated with $0 \cdot 05,0 \cdot 5,2 \cdot 8,5 \cdot 5,10$, or $20 \mathrm{mM}$ glucose and/or peptides at the indicated concentrations for $3 \mathrm{~h}$. At the end of the incubations, special care was taken to identify and isolate by micropunching the $\mathrm{VMH}$ and $\mathrm{LH}$ areas according to the stereotaxic coordinates (Paxinos \& Watson 1986).

\section{Western blot assay}

For immunoblot detection of $\mathrm{GK}, 80 \mu \mathrm{g}$ total protein from VMH and LH areas were resolved by electrophoresis through a SDS-PAGE (9\%). After blocking for $1 \mathrm{~h}$ in PBS-0.1\% Tween 20 containing 5\% BSA, the membranes were incubated with a rabbit anti-GK antibody $(1 / 2000$; a generous gift from Dr J Guinovart, Department de Bioquimica i Biologia Molecular, Universitat de Barcelona, Barcelona, Spain). After washing off excess antibody, the membranes were incubated with an anti-rabbit IgG biotinylated (1:5000) for $1 \mathrm{~h}$ and finally with Streptavidin (Amersham; 1:5000) conjugated to horseradish peroxidase. Chemiluminiscence detection was carried out in the presence of Chemiluminescent HRP Substrate (Millipore, MA, USA). Specificity of GK antibody was tested by the preincubation with or without the antigenic peptide (KLHPSFKERFHASVR).

To map the functional activity of $\mathrm{VMH}$ and $\mathrm{LH}$, the expression of the immediate early gene $c$-fos was determined (Sharp et al. 1993, Chaudhuri et al. 2000). Thus, c-Fos protein was separated by $9 \%$ SDS-PAGE and determined by immunodetection in $\mathrm{VMH}$ and $\mathrm{LH}$ homogenates from hypothalamic slices incubated for $3 \mathrm{~h}$ in the presence of low and high-glucose concentrations (1 and $20 \mathrm{mM}$ ).

\section{Assay of glucose-phosphorylating activities}

The GT1-7 cells or VMH and LH hypothalamic areas were homogenized in ice-cold lysis medium (50 mM HEPES, $150 \mathrm{mM} \mathrm{KCl}, 5 \mathrm{mM} \mathrm{MgCl}_{2}$, and $1 \mathrm{mM}$ EDTA, $\mathrm{pH} \mathrm{7 \cdot 4)}$ supplemented with $1 \mathrm{mM}$ dithiothreitol, $1 \mathrm{mM}$ phenylmethyl-sulfonyl fluoride, and $10 \mu \mathrm{M}$ leupeptin. Homogenates were used to measure enzyme activities.

Glucose-phosphorylation activity analysis involved assays at two glucose concentrations: $0.5 \mathrm{mM}$ for low $\mathrm{Km}$ hexokinase activities, a concentration at which GK is essentially inactive (Bedoya et al. 1984, Nishio et al. 2006), and $25 \mathrm{mM}$ glucose, a concentration at which all phosphotransferase activities were measured. Glucose phosphorylation rates were measured using an isotopic method (Bedoya et al. 1984). In brief, the reaction was initiated by the addition of $10 \mu \mathrm{l}$ soluble fractions of GT1-7 cells or hypothalamic areas to $110 \mu$ total volume of the reaction mixture containing $50 \mathrm{mM}$ HEPES $(\mathrm{pH} \mathrm{7} \cdot 4)$, $150 \mathrm{mM} \mathrm{KCl,} 5 \mathrm{mM} \mathrm{MgCl}$, $5 \mathrm{mM} \mathrm{Mg-ATP,} 10 \mathrm{mM} \mathrm{NaF}$, and 0.5 or $25 \mathrm{mM}$ D-[U- $\left.{ }^{14} \mathrm{C}\right]$ glucose (Amersham Life Science, purity $\geq 98.9 \%$ ), with specific activities of 3.7 or $0.7 \mathrm{mCi} / \mathrm{mmol}$ respectively. The reaction was continued at $30{ }^{\circ} \mathrm{C}$ for $20 \mathrm{~min}$ and stopped by the addition of $30 \mu \mathrm{l} 2 \mathrm{M}$ glucose and $0.25 \mathrm{mM}$ EDTA. Duplicate $60 \mu \mathrm{l}$ samples were spotted onto diethyl amino ethyl (DEAE)-cellulose filters. After washing with distilled water, the filters were dried, and the radioactivity, i.e. the formation of $\left[{ }^{14} \mathrm{C}\right]$ glucose phosphoric esters, was counted by liquid scintillation spectrometry. Blanks without ATP or homogenate were included in each experiment. GK activity was calculated by subtracting the glucose-phosphorylating activity at $0.5 \mathrm{mM}$ glucose from the total activity measured at substrate concentrations of $>5 \mathrm{mM}$.

\section{Statistical analysis}

All values are presented as mean \pm s.E.M. Comparisons among groups were made using ANOVA. $P \leq 0 \cdot 05$ was considered statistically significant.

\section{Results}

Effects of glucose and different peptides on GK gene expression in GT1-7 cells

The action of different glucose concentrations and peptides on GK gene promoter expression was tested in transiently transfected GT1-7 cells. Neither different glucose concentrations $(2 \cdot 8,5 \cdot 5,10$, or $20 \mathrm{mM})$ nor leptin (LEP), glucagonlike peptide 1 (GLP-1) or neuropeptide Y (NPY) were able to modify the promoter activity (Fig. 1) after 5 h of incubation. At the same time, we did not obtain variations in the endogenous GK mRNA levels. However, INS was able to significantly decrease both promoter activity and endogenous GK mRNA.

Effects of glucose and different peptides on GK activities in GT17 cells

Although glucose and different peptides were unable to modify $G K$ gene expression, in an attempt to gain better physiological insight into this process, we tested the activities of GK after GT1-7 cells were incubated with several glucose concentrations and in the absence or presence of GLP-1, LEP, and INS. Whereas, the different glucose concentrations did not change enzyme activities, all peptides tested, except GLP1 decreased GK activities, although this was modulated by the concentrations of glucose. Thus, LEP decreased GK activity at all the glucose concentrations tested, while INS did so at $2 \cdot 8$ and $20 \mathrm{mM}$, and NPY only at $20 \mathrm{mM}$. (Fig. 2). 
A
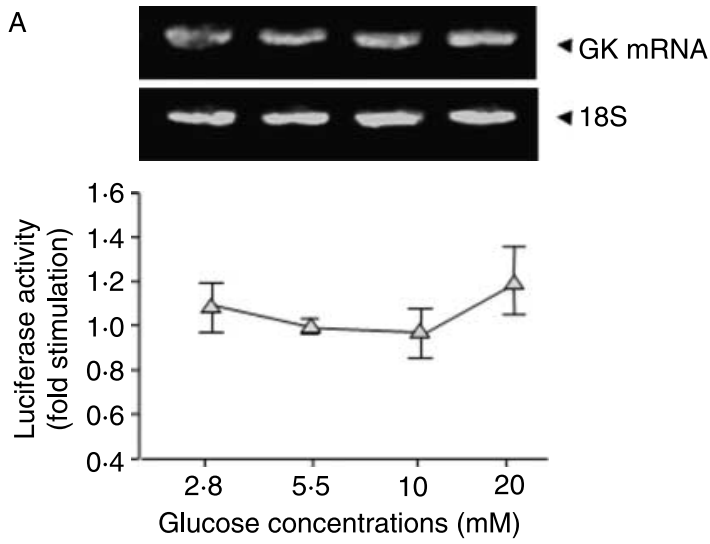

$$
\text { B }
$$

$5.5 \mathrm{mM}$

$20 \mathrm{mM}$

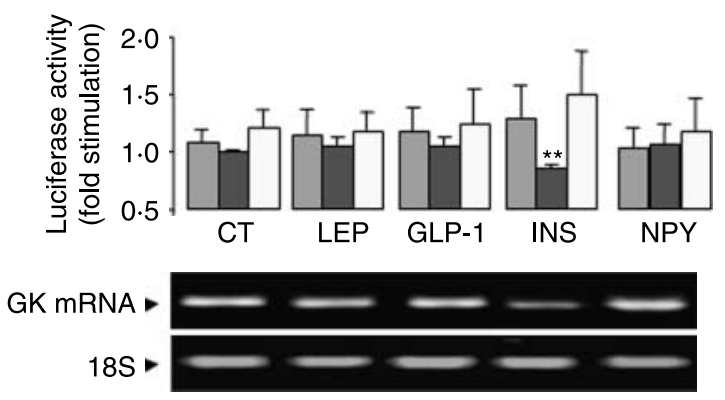

Figure 1 Effects of glucose and orexigenic or anorexigenic peptides on GK promoter activity and endogenous GK mRNA expression in GT1-7 cells. (A) and (B) show the fragments of DNA obtained after PCR amplification of CDNA, and graphics represent the data obtained from the promoter activity studies. Wild-type (panels) GT1-7 cells or cells transiently transfected with a luciferase reporter plasmid containing Gck promoter (graphics), were incubated with $2 \cdot 8,5 \cdot 5,10$, or $20 \mathrm{mM}$ glucose (A) and different peptides (B) $10 \mathrm{nM}$ leptin (LEP), $10 \mathrm{nM} \mathrm{GLP-1,10} \mathrm{nM} \mathrm{insulin} \mathrm{(INS),} \mathrm{or} 100 \mathrm{nM}$ neuropeptide $Y$ (NPY). Data in the graphics are represented as fold increase of GK-luciferase activity (ratio of luciferase to $\beta$ galactosidase activity) relative to the data obtained to $5.5 \mathrm{mM}$ glucose treatment \pm S.E.M. The experiment was repeated at least seven times in duplicate. ${ }^{* *} P \leq 0 \cdot 01$ (INS treatment at $5 \cdot 5 \mathrm{mM}$ glucose versus $5.5 \mathrm{mM}$ glucose without peptide).

\section{Studies in hypothalamic-slices explants}

A further step was to study the effect of glucose on rat hypothalamic slice explants, which constitute a good physiological model because they preserve some tissue architecture and the functional connections involved in glucose sensing and feeding behavior. In these hypothalamic slices cell viability was maintained, as determined by the exclusion of propidium iodide and trypan blue. In addition, after western blot analyses for GK was performed, a specific band corresponding to GK protein was found in both $\mathrm{VMH}$ and $\mathrm{LH}$ areas. The signal was specific since it disappeared, when the membrane was preincubated with the antigenic peptide (Fig. 3A). VMH and $\mathrm{LH}$ areas kept their functional
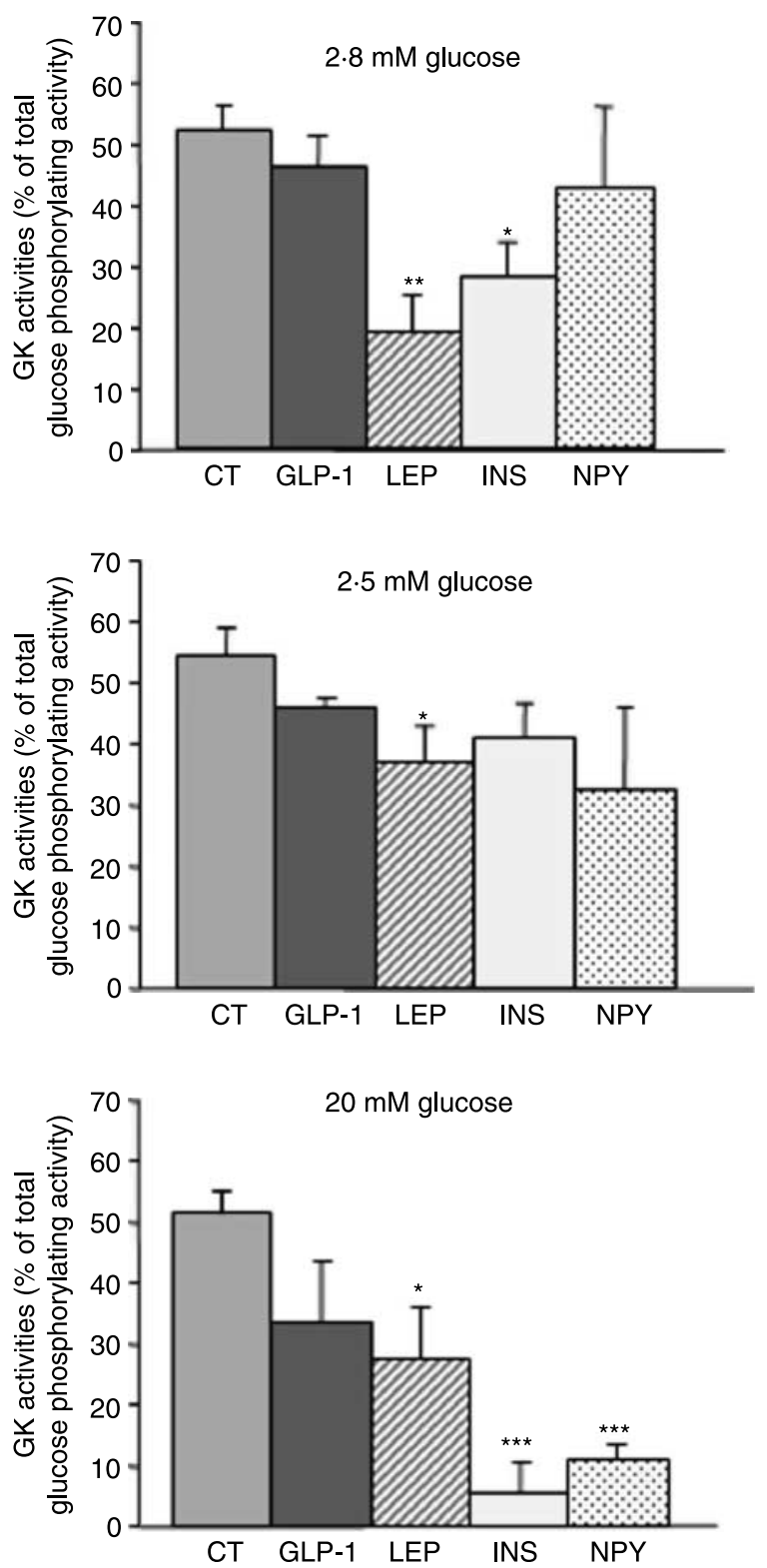

Figure 2 Effects of glucose and orexigenic or anorexigenic peptides on GK enzyme activities in GT1-7 cells. GT1-7 cells were incubated with $2 \cdot 8,5 \cdot 5$, and $20 \mathrm{mM}$ glucose in the absence (CT) or presence of different peptides: $10 \mathrm{nM}$ GLP-1, $10 \mathrm{nM}$ leptin (LEP), $10 \mathrm{nM}$ insulin (INS), and $100 \mathrm{nM}$ neuropeptide Y (NPY). Glucose phosphorylating activities were determined in soluble fractions from GT1-7 cells. Total glucose phosphorylating activity was determined at $25 \mathrm{mM}$ glucose, while low- $\mathrm{Km}$ hexokinase (HK) activities were determined at $0.5 \mathrm{mM}$ glucose, and GK activity was obtained by the difference of individual values at 25 and $0.5 \mathrm{mM}$ glucose. Values of GK activities are given as means \pm S.E.M. and correspond to the percentage of total phosphorylating activities for at least four independent experiments repeated in duplicate. ${ }^{*} P \leq 0 \cdot 05,{ }^{* *} P \leq 0 \cdot 01$, and ${ }^{* * *} P \leq 0 \cdot 001$ (incubated with peptides versus $(\mathrm{T})$. 
A

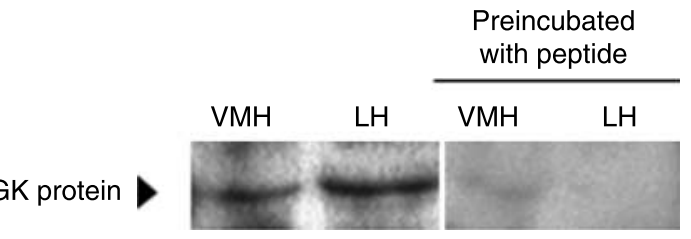

B

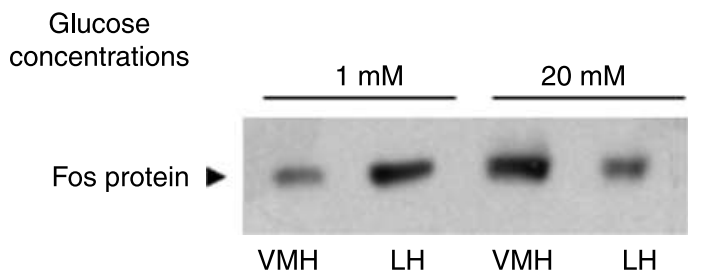

Figure 3 GK protein expression and effects of glucose on Fos protein levels in $\mathrm{VMH}$ and $\mathrm{LH}$ areas. (A) $\mathrm{VMH}$ and $\mathrm{LH}$ areas were dissected from rat hypothalamus, homogenized, and the proteins separated by SDS/PAGE. GK immunoreactivity was detected with an anti-GK antibody (left), while no bands were found when the membrane was preincubated in the presence of GK-antibody plus the immunogenic peptide (right). The figure shows a representative western blot. (B) Hypothalamic slices were incubated for $3 \mathrm{~h}$ in a medium that contained either $1 \mathrm{mM}$ or $20 \mathrm{mM}$ glucose. Thereafter, $\mathrm{VMH}$ and $\mathrm{LH}$ areas were dissected from the hypothalamic slices and homogenized. After SDS-PAGE of hypothalamic extracts, Fos protein was detected by incubation with an anti-Fos antibody. The figure shows a representative western blot.

activity since a high-glucose concentration $(20 \mathrm{mM})$ produced a significant increase in the amount of Fos protein in $\mathrm{VMH}$, but reduced it in LH (Fig. 3B). By contrast, $1 \mathrm{mM}$ glucose had the contrary effect, with a greater appearance of Fos protein band in $\mathrm{LH}$, whereas it was significantly reduced in $\mathrm{VMH}$.

Effect of glucose on GK activities in hypothalamic-slice explants

Glucose concentrations ranging from 0.05 to $20 \mathrm{mM}$ produced changes in GK activities (Fig. 4), depending on the concentration in the extracellular space and on the hypothalamic area tested. Thus, in the VMH a tendency for GK activities to increase was observed when the glucose concentrations rose, while in the LH the tendency was for GK activities to decrease at higher glucose levels (Fig. 4A). However, in the LH a peak of GK activity also appeared at $5.5 \mathrm{mM}$ glucose as compared with 2.8 and $20 \mathrm{mM}$ glucose, GK activities being significantly lower in LH than in VMH at $20 \mathrm{mM}$ glucose (Fig. 4B). The glucose-induced changes in total glucose-phosphorylating activities in the VMH and the LH must be due to the modifications in GK activities because no changes in low-Km hexokinases (HKs) were observed, as shown in Fig. 5, where total glucose phosphorylating and HKs are plotted as a function of the glucose concentration present in the extracellular space. These effects of glucose on
A

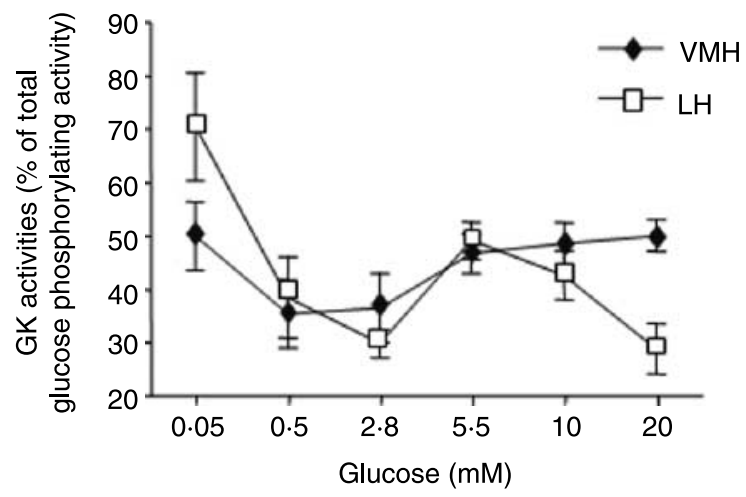

B

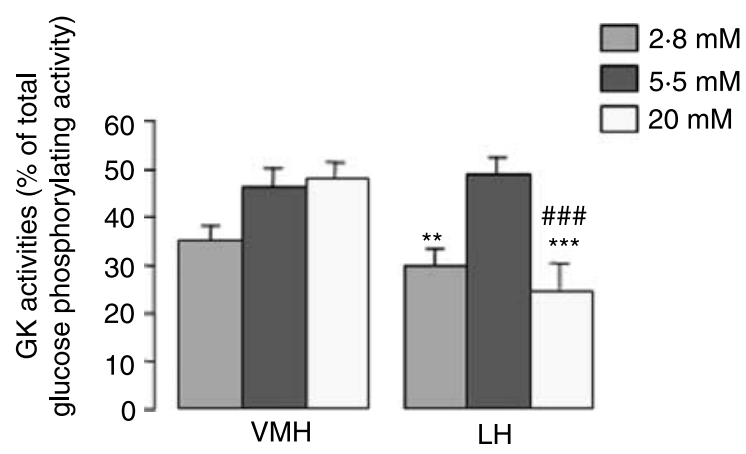

Figure 4 Effects of glucose concentrations on GK enzyme activities in hypothalamic slice explants. The hypothalamic slice-explant cultures were incubated for $3 \mathrm{~h}$ in a medium that contained $0 \cdot 05 \mathrm{mM}, 0 \cdot 5 \mathrm{mM}, 2 \cdot 8,5 \cdot 5,10$, or $20 \mathrm{mM}$ glucose. $\mathrm{VMH}$ and $\mathrm{LH}$ nuclei were dissected from the hypothalamic slices after the incubation period and glucose phosphorylating activities were determined in soluble fractions from these areas, where total glucose phosphorylating activity was determined at $25 \mathrm{mM}$ glucose, while low- $\mathrm{Km}$ hexokinase (HK) activities were determined at $0.5 \mathrm{mM}$ glucose, and GK activity was obtained by the difference of individual values at $25 \mathrm{mM}$ and $0.5 \mathrm{mM}$ glucose. Values of GK activities are given as means \pm s.E.M. and correspond to the percentage of total phosphorylating activities for at least four independent experiments repeated in duplicate. ${ }^{* *} P \leq 0 \cdot 01$ $(2 \cdot 8 \mathrm{mM}$ glucose versus $5.5 \mathrm{mM}), * * * P \leq 0 \cdot 001$ (20 mM glucose versus $5.5 \mathrm{mM}$ ) and ${ }^{\sharp \#} P<0.001$ ( $\mathrm{LH}$ area versus $\mathrm{VMH}$ ).

GK activity seem to be specific, because when we used the L-glucose form, in which biological activity is lacking, we were unable to detect the effects induced by D-glucose (Table 1). To test whether the actions of high-glucose concentrations on GK activity might be produced by hypertonic changes in the cells, we incubated the hypothalamic slices with different concentrations of either sucrose or glucose. Under these conditions, $20 \mathrm{mM}$ sucrose had no effect as compared with the significant reduction in GK activity induced by $20 \mathrm{mM}$ glucose (Fig. 6). 


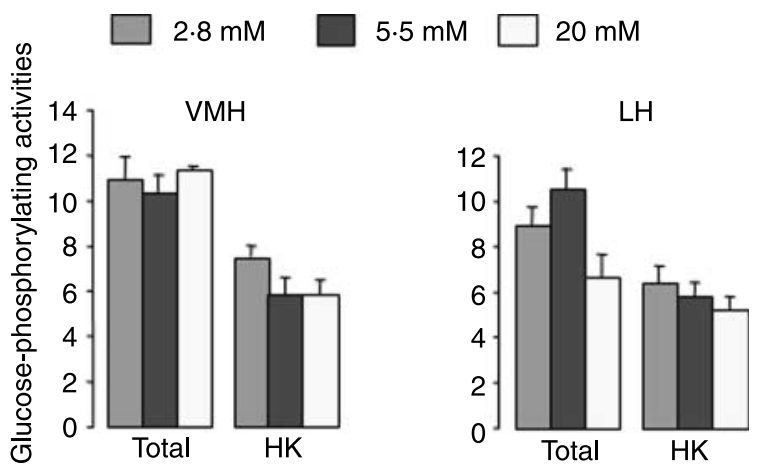

Figure 5 Effects of glucose concentrations on glucose phosphorylating activities in $\mathrm{VMH}$ and $\mathrm{LH}$ areas. The hypothalamic slice-explant cultures were incubated for $3 \mathrm{~h}$ in a medium that contained $2.8 \mathrm{mM}$, $5.5 \mathrm{mM}$, or $20 \mathrm{mM}$ glucose. VMH and LH nuclei were dissected from the hypothalamic slices after the incubation period and glucose phosphorylating activities were determined in soluble fractions from these areas, where total glucose phosphorylating activity was determined at $25 \mathrm{mM}$ glucose, while low-Km hexokinase (HK) activities were determined at $0.5 \mathrm{mM}$ glucose. Values of glucose phosphorylating activities are given as means \pm S.E.M. expressed as pmol of $\left[{ }^{14} \mathrm{C}\right]$ glucose 6 -phosphate/min per $\mu$ g protein for at least four independent experiments repeated in duplicate.

\section{Effect of INS and other peptides on GK activities in} hypothalamic-slice explants

When we tested the effects of different orexigenic and anorexigenic peptides on the GK activities of the VMH and LH (Table 2), we found that GLP-1 and INS did not elicit any changes, whereas LEP, orexin B, and NPY decreased the activities of this enzyme; this effect was statistically significant only in the case of NPY in the LH area.

Although INS did not modify GK activities at $5.5 \mathrm{mM}$ glucose in hypothalamic slices, the effect of higher glucose concentrations $(20 \mathrm{mM})$ reduced GK activity in the LH but not in the VMH and this effect was reversed when tissue slices were incubated with INS (Fig. 7). Thus, when hypothalamic slices were incubated with $5.5 \mathrm{mM}$ glucose and INS no changes were detected in the $\mathrm{VMH}$, whereas in the $\mathrm{LH}$ the addition of $20 \mathrm{mM}$ glucose significantly reduced GK activities, which were recovered after addition of the hormone (Fig. 7).

\section{Discussion}

GK has been characterized in the brains of human (Alvarez et al. 2005) and experimental animals (Jetton et al. 1994, Navarro et al. 1996, Roncero et al. 2000); the isoform present in the central nervous system being similar to that found in pancreatic $\beta$-cells (Roncero et al. 2000), where it seems to contribute as a glucose sensor involved in the control offood intake (Alvarez et al. 1996). These findings open the door to study the effects of glucose and anorexigenic and orexigenic peptides as substances that may potentially modulate the expression of the GK gene and/or the activity of this enzyme in brain.

To accomplish these aims, we used cells of hypothalamic origin such as GT1-7 to study the transcriptional regulation of the GK gene in cells transiently transfected by vectors containing the promoter fused to the luciferase gene. In addition, we determined the catalytic activities of this enzyme. There is experimental evidence that GT1-7 cells are glucose-sensing cells (Mellon et al. 1990, Lee et al. 2005) able to respond to glucose deprivation or high-glucose levels, as well as having intrinsic GK activity (data not shown). They represent a model for studying the transcriptional regulation of GK gene since the transfection method cannot be applied to other systems, including hypothalamic slices. However, immortalized cell lines are limited in studies of transcriptional activity because they are not located within a complex neuronal network. Thus, a further step was the use of rat hypothalamic slices, which represent an experimental design of physiological relevance because they preserve some of the tissue architecture and the functional connections involved in feeding behavior. In addition, they contain GE and GI neurons with GK activities, and receptors to different peptides, and they retained a selective c-Fos expression in response to different glucose concentrations, indicating that these hypothalamic areas preserve the functional activity found in the whole animal (Solomon et al. 2006). These findings and the distinctive effects of different glucose concentrations and peptides on GK activities in the VMH and the LH underscore the relevance of this experimental design, as the time that remark the selective functional activities of both hypothalamic areas.

GK is considered to be a true glucose sensor present in GE and GI neurons where it seems to be implicated in glucose sensing (Navarro et al. 1996). This dependence on GK has

Table 1 Glucose phosphorylating activities in ventromedial hypothalamus (VMH) and lateral hypothalamus (LH) areas incubated with $20 \mathrm{mM}$ D-glucose or L-glucose. Values represent means \pm s.E.M. $(n)$ expressed as pmol of $\left[{ }^{14} \mathrm{C}\right]$ glucose 6 -phosphate/min per $\mu \mathrm{g}$ protein

\begin{tabular}{|c|c|c|c|c|c|c|}
\hline \multicolumn{4}{|c|}{$20 \mathrm{mM}$ D-glucose } & \multicolumn{3}{|c|}{$20 \mathrm{mM}$ L-glucose } \\
\hline & Total & $\mathrm{HK}$ & GK & Total & HK & GK \\
\hline $\mathrm{VMH}$ & $11 \cdot 5 \pm 0 \cdot 8(16)$ & $5 \cdot 8 \pm 0 \cdot 4(16)$ & $5 \cdot 7 \pm 0 \cdot 6(16)$ & $12 \cdot 0 \pm 0 \cdot 8(5)$ & $8 \cdot 0 \pm 0 \cdot 5(5)$ & $3 \cdot 9 \pm 0 \cdot 6(5)$ \\
\hline $\mathrm{LH}$ & $7 \cdot 6 \pm 1 \cdot 0(12)$ & $5 \cdot 6 \pm 0 \cdot 6(10)$ & $2 \cdot 3 \pm 0 \cdot 6(12)^{*}$ & $11 \cdot 3 \pm 1 \cdot 6(5)$ & $6 \cdot 9 \pm 1 \cdot 1(5)$ & $4 \cdot 3 \pm 1 \cdot 3(5)$ \\
\hline
\end{tabular}

$* P<0 \cdot 001$ when values obtained in $\mathrm{VMH}$ and $\mathrm{LH}$ incubated at $20 \mathrm{mM}$ D-glucose were compared. 


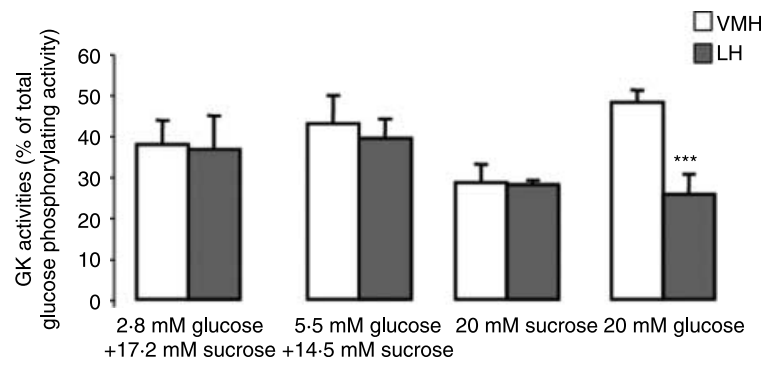

Figure 6 Effects of $20 \mathrm{mM}$ glucose on GK activities in LH were not produced by hypertonic change on the cells. The hypothalamic slice-explant cultures were incubated for $3 \mathrm{~h}$ in a medium that contained the indicated concentration of glucose and sucrose. In all cases, the final concentrations of sugars in the extracellular medium were $20 \mathrm{mM}$. VMH and $\mathrm{LH}$ nuclei were dissected from the hypothalamic slices after the incubation period and glucose phosphorylating activities were determined in soluble fractions from these areas. Values of GK activities are given as means \pm S.E.M. for at least three independent experiments repeated in duplicate. ${ }^{* * *} P \leq 0 \cdot 001$ ( $\mathrm{LH}$ versus $\mathrm{VMH}$ ).

recently been confirmed by demonstrating that transfected cultured VMH neurons with GK siRNA almost completely abolished neuron glucose sensing, and that pharmacological activation of GK increased the sensitivity of glucose-sensing neurons to glucose (Kang et al. 2006).

Neither the promoter activity of the GK gene in transfected GT1-7 cells nor the endogenous GK gene expression were modified by the action of different concentrations of glucose or GLP-1, LEP, or NPY in the extracellular space. However, GK enzyme activities were modified by these molecules, suggesting that alterations may be induced through short-term processes rather than by longer-term mechanisms involved in $G K$ gene expression. In this sense, we cannot discard other short-term effects, i.e. the interactions of GK and GKRP present in the hypothalamus of rat and human brain (Alvarez et al. 2002, 2005) or GK-PFK2 interaction as occurs in liver and $\beta$-cells (Massa et al. 2004, Baltrusch \& Tiedge 2006).

In previous reports, we described the presence of GK mRNA and protein in rat (Navarro et al. 1996, Roncero et al. 2000) and human (Roncero et al. 2004) brains, with similar kinetic properties as the enzyme from liver and pancreatic islets. In this work, we present experimental evidence of the existence of GK protein and activities in VMH and $\mathrm{LH}$ areas, which permits comparative analyses between different hypothalamic areas, such as we observed in the VMH and
LH in response to glucose. Whereas in GT1-7 cells, glucose did not modify the expression of GK gene and GK activity at the time studied, in the VMH there was a tendency for GK activities to increase as glucose rose in the extracellular media and high-GK activity was found at lower glucose concentrations in the LH. These findings could reflect a different type of behavior for the GE and GI neurons located in the VMH and the LH, when challenged by different concentrations of glucose. This would be in agreement with the tendency of GK activity to increase with rises in glucose in the range of $0.5-20 \mathrm{mM}$ that we found in the $\mathrm{VMH}$, while neurons in LH were not excited by the higher concentrations of glucose but by lower concentrations of this hexose, as happens with GK activities. The observed changes in GK activity in response to glucose in certain hypothalamic areas suggest that such activity would not only be tissue-specific but also even cell-specific in defined brain areas.

Since the concentrations of extracellular glucose in the brain seem to be lower than those in blood (from 0.5 to $4.5 \mathrm{mM}$; Silver \& Erecinska 1994), we used a broad range of glucose concentrations from $0 \cdot 05$ to $20 \mathrm{mM}$ in order to get general information of the effects of glucose on GK activities. We did observe effects of glucose not only within this range but also at $20 \mathrm{mM}$ glucose; this could be explained in terms of the presence of neurons that are stimulated by an increase from 5 to $20 \mathrm{mM}$ glucose (Fioramonti et al. 2004). Obviously, $20 \mathrm{mM}$ glucose can be considered as a pharmacological concentration, but these levels may be found in the blood of uncontrolled diabetic patients and from a pathophysiological point of view the results obtained under this circumstance may be of interest. Interestingly, GK activities were significantly lower in LH than in VMH at $20 \mathrm{mM}$, but this effect was reversed by the presence of INS. This distinctive response observed in LH at $20 \mathrm{mM}$ glucose may be related to different functional activities of these two areas, rather than to other kind of effects. Thus, the effects were induced by Dglucose but not by L-glucose, and the changes in total glucose-phosphorylating activities were due to modifications in GK but not in HKs. In addition, the hypertonic effect of high-glucose concentrations used was not responsible for the observed modifications in GK since similar concentrations of sucrose did not modify the enzyme activities.

Since we have previously proposed that GK may be a glucose sensor in brain (Navarro et al. 1996) implicated in the control of food ingestion, and orexigenic and anorexigenic peptides play important roles on feeding behavior, we tested

Table 2 Glucokinase activities as percentage of total glucose phosphorylating activity in hypothalamic slices (ventromedial hypothalamus, $\mathrm{VMH}$ and lateral hypothalamus, $\mathrm{LH}$ areas) incubated in the presence of $5.5 \mathrm{mM}$ glucose with or without ( - ) peptides. Values are means \pm S.E.M. $(n)$

\begin{tabular}{|c|c|c|c|c|c|c|}
\hline & - & GLP-1 & LEP & OREX & INS & NPY \\
\hline $\mathrm{VMH}$ & $54 \cdot 9 \pm 6 \cdot 6(8)$ & $51 \cdot 4 \pm 6 \cdot 4(7)$ & $40 \cdot 9 \pm 10 \cdot 8$ & $36 \cdot 7 \pm 5 \cdot 7(4)$ & $50 \cdot 2 \pm 8 \cdot 5(6)$ & $37 \cdot 8 \pm 26 \cdot 4(2)$ \\
\hline $\mathrm{LH}$ & $53 \cdot 3 \pm 5 \cdot 6(8)$ & $47 \cdot 9 \pm 6 \cdot 0(7)$ & $48 \cdot 7 \pm 7 \cdot 0(4)$ & $43 \cdot 9 \pm 11 \cdot 0(4)$ & $52 \cdot 6 \pm 8 \cdot 3(6)$ & $35 \cdot 0 \pm 6 \cdot 5(4)^{*}$ \\
\hline
\end{tabular}

$* P<0.05$ compared with $(-)$ condition. GLP-1, glucagon-like peptide 1; LEP, leptin; OREX, orexin-B; INS, insulin; NPY, neuropeptide Y. 


\section{$5.5 \mathrm{mM}$ glucose}

$20 \mathrm{mM}$ glucose
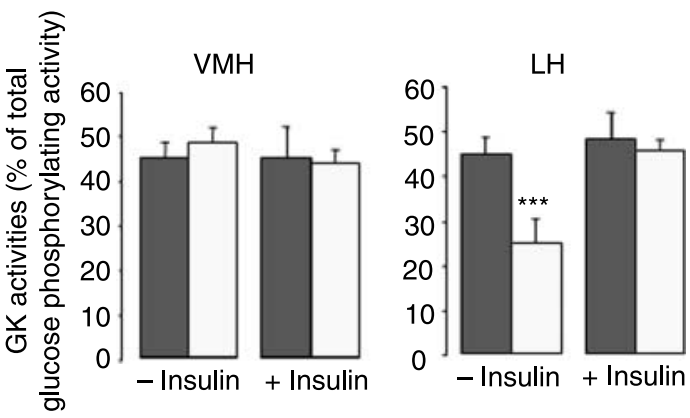

Figure 7 Efffect of insulin and $20 \mathrm{mM}$ glucose on GK activities in $\mathrm{LH}$. The hypothalamic slice-explant cultures were incubated for $3 \mathrm{~h}$ in a medium that contained 5.5 or $20 \mathrm{mM}$ glucose in the presence or absence of $10 \mathrm{nM}$ insulin. $\mathrm{VMH}$ and $\mathrm{LH}$ nuclei were dissected from the hypothalamic slices after the incubation period and glucose phosphorylating activities were determined in soluble fractions from these areas. Values of GK activities are given as means \pm S.E.M. for at least three independent experiments repeated in duplicate. ${ }^{* *} P \leq 0 \cdot 001(5 \cdot 5 \mathrm{mM}$ glucose versus $20 \mathrm{mM}$ glucose)

the effects of these peptides on GK gene expression and GK enzyme activities. Although these peptides did not modify the transcriptional activity of the GK gene in GT1-7 cells except for a significant negative effect of INS, these peptides did alter the GK activities in GT1-7 cells and in the VMH and LH. In this way, we have found in humans after the evaluation of cerebral glucose metabolism in control subjects by positron emission tomography, using 2-[F-18]deoxy-D-glucose, that GLP-1 modified cerebral glucose metabolism in hypothalamus and brainstem (Alvarez et al. 2005).

The expression of hepatic (L1) and the pancreatic islet (B1) functional GK isoforms is controlled in a different way since liver GK is regulated by INS, whereas the pancreatic enzyme seems to be controlled posttranslationally by glucose levels (Bedoya et al. 1986). However, in recent years it has been reported (Leibiger et al. 2001, Da Silva Xavier et al. 2004) that INS positively regulates $G K$ gene transcription in pancreatic $\beta$ cells . Additionally we have found a similar RNA splicing of the $G K$ gene product in rat hypothalamus (Roncero et al. 2000) and pancreatic islets; the mRNA that codes for the $B_{1}$ isoform was the most abundant at both locations, which poses the question of whether the control of $G K$ gene expression and enzyme activity in the hypothalamus would be modulated by INS and/or by glucose. At the time studied, our data revealed that changes in glucose levels were unable to stimulate the transcriptional activity of the GK gene in GT1-7 cells, although INS was the only peptide assayed that inhibited both $G K$ gene transcription and enzyme activity, indicating that this isoform may differ as compared with those of liver or pancreatic origin.

In conclusion, our findings indicate that in most of the cases modifications of GK occur at the enzyme activity level rather than in transcriptional expression, suggesting that if GK acts as a glucose sensor involved in feeding behavior it requires changes in short rather than longer periods of time, i.e. alterations in GK activity rather than in gene expression. Moreover, the distinctive pattern of GK activities of ventromedial and lateral hypothalamic areas would be conditioned by the action of GE and GI neurons in such locations and their potential role in glucose sensing. Finally, the effect of orexigenic (NPY and orexin) and anorexigenic (LEP, GLP-1 and INS) peptides on GK activities raise further questions about the action of these molecules in glucose sensing and nutrient homeostasis in the brain.

\section{Acknowledgements}

The authors are indebted to Prof. Magnuson, Prof. J Guinovart and Prof. P Mellon for their generous gifts of the GK promoter, GK antibody, and GT1-7 cell line respectively. This work was supported by grants from the Fondo de Investigación Sanitaria, Instituto de Salud Carlos III. (PI060153, PIO 20232, RGDM 03/2/2) and Red de Diabetes y Enfermedades Metabólicas Asociadas REDIMET (RD 06/0015/0017), the Ministerio de Ciencia y Tecnología (BFI 2003-05617 and SAF 2006-04075) and the Comunidad de Madrid, Spain. M A N was supported by the Ramón y Cajal Program of the Spanish Ministry of Education and Science. The authors declare that there is no conflict of interest that would prejudice the impartiality of this scientific work.

\section{References}

Alvarez E, Roncero I, Chowen JA, Thorens B \& Blazquez E 1996 Expression of the glucagon-like peptide-1 receptor gene in rat brain. Journal of Neurochemistry 66 920-927.

Alvarez E, Roncero I, Chowen JA, Vazquez P \& Blazquez E 2002 Evidence that glucokinase regulatory protein is expressed and interacts with glucokinase in rat brain. Journal of Neurochemistry 80 45-53.

Alvarez E, Martinez MD, Roncero I, Chowen JA, Garcia-Cuartero B, Gispert JD, Sanz C, Vazquez P, Maldonado A, de Caceres J et al. 2005 The expression of GLP-1 receptor mRNA and protein allows the effect of GLP-1 on glucose metabolism in the human hypothalamus and brainstem. Journal of Neurochemistry 92 798-806.

Arima H, House SB, Gainer H \& Aguilera E 2001 Direct stimulation of arginine vasopressin gene transcription by cAMP in parvocellular neurons of the paraventricular nucleus in organotypic cultures. Endocrinology 142 5027-5030.

Baltrusch S \& Tiedge M 2006 Glucokinase regulatory network in pancreatic $\beta$-cells and liver. Diabetes 55 S55-S64.

Bedoya FJ, Ramirez R, Arilla E \& Goberna R 1984 Effect of 2-bromostearate on glucose-phosphorylating activities and the dynamic of insulin secretion in islets of Langerhans during fasting. Diabetes 33 858-863.

Bedoya FJ, Matschinsky FM, Shimizu T, O’Neil JJ \& Appel MC 1986 Differential regulation of glucokinase activity in pancreatic islets and liver of the rat. Journal of Biological Chemistry 261 10760-10764.

Chaudhuri A, Zangenehpour S, Rahbar-Dehgan F \& Ye F 2000 Molecular maps of neural activity and quiescence. Acta Neurobiologiae Experimentalis 60 403-410.

Dipietro DL, Sharma C \& Weinhouse S 1962 Studies on glucose phosphorylation in rat liver. Biochemistry 1 455-462. 
Dunn-Meynell AA, Rawson NE \& Levin BE 1998 Distribution and phenotype of neurons containing the ATP-sensitive $\mathrm{K}^{+}$channel in rat brain. Brain Research $\mathbf{8 1 4}$ 41-54.

Dunn-Meynell AA, Routh VH, Kang L, Gaspers L \& Levin BE 2002 Glucokinase is the likely mediator of glucosensing in both glucose-excited and glucose-inhibited central neurons. Diabetes 51 2056-2065.

Fioramonti X, Lorsignol A, Taupignon A \& Penicaud L 2004 A new ATPsensitive $\mathrm{K}^{+}$channel-independent mechanism is involved in glucoseexcited neurons of mouse arcuate nucleus. Diabetes $\mathbf{5 3}$ 2767-2775.

House SB, Thomas A, Kusano K \& Ganier H 1998 Stationary organotypic cultures of oxytocin and vasopressin magnocellular neurones from rat and mouse hypothalamus. Journal of Neuroendocrinology 10 849-861.

Jetton TL, Liang Y, Pettepher CC, Zimmerman EC, Cox FG, Horvath K, Matschinsky FM \& Magnuson MA 1994 Analysis of upstream glucokinase promoter activity in transgenic mice and identification of glucokinase in rare neuroendocrine cells in the brain and gut. Journal of Biological Chemistry 269 3641-3654.

Kang L, Dunn-Meynell AA, Routh VH, Gaspers LD, Nagata Y, Nishimura T, Eiki J, Zhang BB \& Levin BE 2006 Glucokinase is a critical regulator of ventromedial hypothalamic neuronal glucosensing. Diabetes 55 412-420.

Lee K, Li B, Xi X, Suh Y \& Martin RJ 2005 Role of neuronal energy status in the regulation of adenosine 5'-monophosphate-activated protein kinase, orexigenic neuropeptides expression, and feeding behavior. Endocrinology $1463-10$.

Leibiger B, Leibiger IB, Moede T, Kemper S, Kulkarni RN, Kahn CR, de Vargas LM \& Berggren P-O 2001 Selective insulin signaling through A and $\mathrm{B}$ insulin receptors regulates transcription of insulin and glucokinase genes in pancreatic $\beta$ cells. Molecular Cell $7559-570$.

Magnuson MA \& Shelton KD 1989 An alternate promoter in the glucokinase gene is active in the pancreatic beta cell. Journal of Biological Chemistry 264 15936-15942.

Massa L, Baltrusch S, Okar DA, Lange AJ, Lenzen S \& Tiedge M 2004 Interaction of 6-phosphofructo-2-kinase/fructose-2,6-bisphosphatase (PFK-2/FBPase-2) with glucokinase activates glucose phosphorylation and glucose metabolism in insulin-producing cells. Diabetes 53 1020-1029.

Matschinsky FM 1990 Glucokinase as glucose sensor and metabolic signal generator in pancreatic beta-cells and hepatocytes. Diabetes 39 647-652.

Matschinsky FM \& Ellerman JE 1968 Metabolism of glucose in the islets of Langerhans. Journal of Biological Chemistry 243 2730-2736.

Mellon PL, Windle JJ, Goldsmith PC, Padula CA, Roberts JL \& Weiner RI 1990 Immortalization of hypothalamic GnRH neurons by genetically targeted tumorogenesis. Neuron $\mathbf{5}$ 1-10.

Navarro M, Rodriquez de Fonseca F, Alvarez E, Chowen JA, Zueco JA, Gomez R, Eng J \& Blazquez E 1996 Colocalization of glucagon-like peptide-1 (GLP-1) receptors, glucose transporter GLUT-2, and glucokinase mRNAs in rat hypothalamic cells: evidence for a role of GLP-1 receptor agonists as an inhibitory signal for food and water intake. Journal of Neurochemistry 67 1982-1991.
Niimi M, Sato M, Tamaki M, Wada Y, Takahara J \& Kawanishi K 1995 Induction of Fos protein in the rat hypothalamus elicited by insulin-induced hypoglycemia. Neuroscience Research 23 361-364.

Nishio T, Toyoda Y, Hiramatsu M, Chiba T \& Miwa I 2006 Decline in glucokinase activity in the arcuate nucleus of streptozotocin-induced diabetic rats. Biological and Pharmaceutical Bulletin 29 216-219.

Oomura Y, Ono T, Ooyama H \& Wayner MJ 1969 Glucose and osmosensitive neurones of the rat hypothalamus. Nature 222 282-284.

Paxinos G \& Watson C 1986 The Rat Brain in Stereotaxic Coordinates., New York: Academic Press.

Printz RL, Magnuson MA \& Granner DK 1993 Mammalian glucokinase. Annual Review of Nutrition 13 463-496.

Roncero I, Alvarez E, Vázquez P \& Blázquez E 2000 Functional glucokinase isoforms are expressed in rat Brain. Journal of Neurochemistry 74 1848-1857.

Roncero I, Alvarez E, Chowen JA, Sanz C, Rabano A, Vazquez P \& Blazquez E 2004 Expression of glucose transporter isoform GLUT-2 and glucokinase genes in human brain. Journal of Neurochemistry 88 1203-1210.

Sharp FR, Sagar SM \& Swanson RA 1993 Metabolic mapping with cellular resolution: c-fos vs. 2-deoxy-glucose. Critical Reviews in Neurobiology 7 205-228.

Shelton KD, Franklin A, Khoor A, Beechem J \& Magnuson MA 1992 Multiple elements in the upstream glucokinase promoter are necessary for transcription in insulinoma cells. Molecular and Cellular Biology 12 4578-4589.

Da Silva Xavier G, Qian Q, Cullen PJ \& Rutter GA 2004 Distinct roles for insulin and insulin-like growth factor-1 receptors in pancreatic betacell glucose sensing revealed by RNA silencing. Biochemical Journal 377 149-158.

Silver IA \& Erecinska M 1994 Extracellular glucose concentrations in mammalian brain: conditions monitoring of changes during increased neural activity and upon limitation in oxygen supply in normo-, hypo- and hyperglycemic animals. Journal of Neuroscience 14 5068-5076.

Solomon A, De Fanti BA \& Martinez JA 2006 Peripheral ghrelin participates in the glucostatic signaling mediated by the ventromedial and lateral hypothalamus neurons. Peptides 27 1607-1615.

Viñuela E, Salas M \& Sols A 1963 Glucokinase and hexokinase in liver in relation to glycogen synthesis. Journal of Biological Chemistry 238 $1175-1177$.

Wetsel WC 1995 Immortalized hypothalamic luteinizing hormone-releasing hormone (LHRH) neurons: a new tool for dissecting the molecular and cellular basis for LHRH physiology. Cellular and Molecular Neurobiology 15 $43-78$.

Received in final form 6 March 2007

Accepted 12 March 2007

Made available online as an Accepted Preprint 13 March 2007 